DEPARTMENT OF THE INTERIOR

UNITED STATES GEOLOGICAL SURVEY

\title{
SURFICIAL GEOLOGIC MAP OF THE NATICK QUADRANGLE, MIDDLESEX AND NORFOLK COUNTIES, MASSACHUSETTS
}

\author{
By Arthur E. Nelson
}

Prepared in cooperation with

THE COMMONWEALTH OF MASSACHUSETTS

DEPARTMENT OF PUBLIC WORKS 